\section{Cureus}

Received 09/18/2015

Review began 10/10/2015

Review ended 12/17/2015

Published 12/17/2015

\section{(C) Copyright 2015}

Redmond et al. This is an open access article distributed under the terms of the Creative Commons Attribution License CC-BY 3.0., which permits unrestricted use, distribution, and reproduction in any medium, provided the original author and source are credited.

\title{
Stereotactic Radiosurgery for Glioblastoma
}

\author{
Kristin J. Redmond ${ }^{1}$, Minesh Mehta ${ }^{2}$ \\ 1. Department of Radiation Oncology and Molecular Radiation Sciences, The Johns Hopkins University \\ School of Medicine 2. Department of Radiation Oncology, University of Maryland
}

$\square$ Corresponding author: Kristin J. Redmond, kjanson3@jhmi.edu

Disclosures can be found in Additional Information at the end of the article

\section{Abstract}

Glioblastoma (GBM) is the most common primary malignant brain tumor in adults and one of the most aggressive of all human cancers. GBM tumors are highly infiltrative and relatively resistant to conventional therapies. Aggressive management of GBM using a combination of surgical resection, followed by fractionated radiotherapy and chemotherapy has been shown to improve overall survival; however, GBM tumors recur in the majority of patients and the disease is most often fatal. There is a need to develop new treatment regimens and technological innovations to improve the overall survival of GBM patients. The role of stereotactic radiosurgery (SRS) for the treatment of GBM has been explored and is controversial. SRS utilizes highly precise radiation techniques to allow dose escalation and delivery of ablative radiation doses to the tumor while minimizing dose to the adjacent normal structures. In some studies, SRS with concurrent chemotherapy has shown improved local control with acceptable toxicities in select GBM patients. However, because GBM is a highly infiltrative disease, skeptics argue that local therapies, such as SRS, do not improve overall survival. The purpose of this article is to review the literature regarding SRS in both newly diagnosed and recurrent GBM, to describe SRS techniques, potential eligible SRS candidates, and treatment-related toxicities. In addition, this article will propose promising areas for future research for SRS in the treatment of GBM.

\section{Categories: Radiation Oncology, Neurosurgery, Oncology}

Keywords: stereotatic radiosurgery, brain tumor, gamma knife radiosurgery, recurrent glioblastoma, glioblastoma multiforme

\section{Introduction And Background}

Glioblastoma (GBM) is the most common primary malignant brain tumor and is one of the most aggressive of all human cancers. The National Cancer Institute estimates that there will be 23,380 newly diagnosed brain or other nervous system tumors in 2014 , with an estimated 14,320 deaths [1]. GBM accounts for approximately $15 \%$ of all brain tumors and primarily occurs in adults between the ages of 45 and 70. The symptoms of GBM vary depending on the location of the tumor but may include persistent headaches, seizures, vision changes, nausea, vomiting, loss of appetite, difficulty with speech, changes in mood and behavior, mental capacity and concentration, cranial nerve deficits, and motor or sensory abnormalities. The putative cell of origin of this rapidly proliferating tumor with a high growth fraction is the astrocyte, and the World Health Organization (WHO) classifies this as a Grade IV astrocytoma. These tumors are generally highly infiltrative and relatively resistant to conventional therapies, such as surgery, radiation therapy, and chemotherapy. The disease is generally associated with rapid progression and fatal outcomes, typically resulting in death in the first 15 months or less after diagnosis, with very small numbers of long-term survivors. 
The standard of care following maximal safe resection is fractionated radiation therapy to 60 Gray (Gy) in 30 fractions, plus temozolomide chemotherapy (concomitant with radiation therapy, and adjuvantly for six monthly cycles) based on a randomized controlled trial, which demonstrated a significant improvement in overall survival compared to patients receiving radiation therapy alone [2-3]. In spite of aggressive management, this tumor recurs in the majority of patients and the disease is almost universally fatal. Given the poor prognosis, developing innovative new methods for managing this disease are essential.

Whereas conventionally fractionated radiation therapy allows safe treatment of large volumes by taking advantage of the differential rates of repair between normal tissue and tumor cells, stereotactic radiosurgery (SRS) utilizes highly precise radiation techniques to allow dose escalation and delivery of ablative radiation doses to the tumor while minimizing dose to the adjacent normal structures. Recent technological advances allow submillimeter precision and the possibility of fractionation.

The role of SRS in the management of glioblastoma is controversial [4]. Radiation therapy is the single most effective adjuvant therapy following surgical resection for GBM. Studies have shown that GBM recurrences predominantly occur within a $2 \mathrm{~cm}$ border of the original tumor following resection and radiation therapy [5]. Given that GBM recurrences are predominantly local, proponents of radiosurgery note that it allows dose escalation while limiting exposure to adjacent critical structures. Skeptics report that GBM is a highly infiltrative disease that extends beyond the radiographically apparent margins, making utilization of a highly conformal technique counterintuitive.

The purpose of this manuscript is to review the literature regarding SRS in both newly diagnosed and recurrent GBM and to describe the technique as well as potential candidates for it. In addition, we will discuss toxicities and propose promising areas for future research.

\section{Review}

\section{SRS in newly diagnosed GBM}

The only Level I data evaluating the efficacy of SRS in patients with newly diagnosed GBM comes from RTOG 9305, which randomized 203 patients with supratentorial GBM measuring less than $4 \mathrm{~cm}$ to external beam radiation therapy (60 Gy), plus bis-chloroethylnitrosourea (BCNU) chemotherapy with or without an upfront SRS boost [6]. The SRS radiation doses were dependent on the tumor size but ranged from 15 to $24 \mathrm{~Gy}$ delivered in a single fraction. There was no difference in median overall survival, two and three-year overall survival rates, or in the pattern of failure between the two treatment groups. In addition, quality of life and cognitive outcomes were comparable between the two groups.

Compellingly negative as these results are, they are less directly applicable to the current standard of care management, which involves concurrent and adjuvant temozolomide, a regimen more likely to control infiltrative microscopic disease beyond the SRS boost region [23]. Local failure in GBM is likely a consequence of at least two separate phenomena: one representing inadequate dose (which can be rectified with an SRS boost), and the other representing geographic failure due to microscopic extension beyond the SRS margin (which currently can only be addressed with temozolomide). Because SRS can influence only one of these failure mechanisms, a contemporary trial combining temozolomide with an SRS boost is called for. In fact, in one report from UCSF where GBM patients undergoing SRS were evaluated with MR spectroscopy (MRS), patients with significant abnormal magnetic resonance spectroscopy (MRS) outside the SRS dose region relapsed rapidly and appear not to benefit, implying the need for another therapeutic approach to control infiltrative microscopic disease at some distance from the SRS dose margin [7]. Some critics have suggested that in RTOG 9305 
SRS was delivered prior to conventional radiation therapy, and that perhaps the alternative strategy to consider is to complete conventional radiotherapy and temozolomide and use SRS boost as a randomized comparator only in those patients whose disease has not progressed, thereby allowing the selection of a cohort of patients most likely to benefit from SRS [8].

Another multi-institutional study, RTOG 0023, a Phase II study, enrolled 76 patients with newly diagnosed GBM with $<6 \mathrm{~cm}$ of residual contrast-enhancing tumor and provided intriguing insights for patient selection [8]. In this trial, patients were treated with $50 \mathrm{~Gy}$ conventional radiation therapy with four fractionated stereotactic radiosurgery boost fractions of either 5 or 7 Gy administered once weekly during the final four weeks of therapy. This study also used BCNU, rather than temozolomide. While the regimen was safe, there was no survival benefit compared to the historical RTOG database for the entire cohort; however, the patient subset undergoing complete or near-complete resection, in fact, did appear to have improved survival with this boost approach, suggesting that perhaps minimal to no residual disease might represent an important selection parameter.

In contrast, a number of retrospective reports as well as single institution prospective studies evaluating SRS in combination with EBRT, with or without chemotherapy, including temozolomide, have suggested a potential local control or overall survival benefit with variable, but generally acceptable, toxicity [9-19]. See Table 1 for a summary of published results for SRS treatment of newly diagnosed glioblastoma. 


\section{Cureus}

\begin{tabular}{|c|c|c|c|c|}
\hline Author & $\mathbf{N}$ & Treatment Schema & Survival Rate & $\begin{array}{l}\text { Median OS } \\
\text { (months) }\end{array}$ \\
\hline Sarkaria [9] & 115 & 54-60 Gy RT + 6-20 Gy SRS & $\begin{array}{l}\text { 2-yr OS: } 45 \% 2 \text { 2-yr OS for KPS } \geq \\
70: 51 \% 2-y r \text { OS for KPS < } 70: \\
0 \%\end{array}$ & NR \\
\hline Gannett [10] & 30 & 44-62 Gy RT + 0.5-18 Gy SRS & 1-yr DSS: $57 \%$ 2-yr DSS: $25 \%$ & 13.9 \\
\hline $\begin{array}{l}\text { Masciopinto } \\
{[11]}\end{array}$ & 31 & RT + 15-35 Gy SRS & 1-yr OS: $37 \%$ & 9.5 \\
\hline Mehta [12] & 31 & 54 Gy RT + 15-30 Gy SRS & 1-yr OS: $38 \%$ 2-yr OS: $28 \%$ & 42 weeks \\
\hline $\begin{array}{l}\text { Nwokedi } \\
{[13]}\end{array}$ & $\begin{array}{l}33 \mathrm{RT} \\
\text { alone; } 31 \\
\mathrm{RT}+\mathrm{SRS}\end{array}$ & $\begin{array}{l}\text { 28-80 (median 59.7) Gy RT + 10-28 } \\
\text { (median 7.1 Gy) SRS }\end{array}$ & $\begin{array}{l}\text { For all patients: } 1 \text {-yr OS: } 67 \% \text { 2- } \\
\text { yr OS: } 40 \% 3 \text { yr OS: } 26 \%\end{array}$ & $\begin{array}{l}\text { RT alone: } \\
\text { 13 RT + } \\
\text { SRS: } 25\end{array}$ \\
\hline $\begin{array}{l}\text { Balducci } \\
\text { [14] }\end{array}$ & $\begin{array}{l}41(36 \\
\text { GBM, } 5 \text { AA) }\end{array}$ & $\begin{array}{l}59.4 \text { Gy or } 50.4 \text { Gy RT }+10 \text { or } 19 \text { Gy } \\
\text { SRS (total dose of } 69.4 \text { Gy) }+ \\
\text { temozolomide }\end{array}$ & 2-yr OS: $63 \%$ & $\begin{array}{l}\text { All pts: } 30 \\
\text { GBM: } 28\end{array}$ \\
\hline $\begin{array}{l}\text { Cardinale } \\
\text { [15] }\end{array}$ & $\begin{array}{l}9 \text { GBM } 3 \\
\text { AA }\end{array}$ & 44 Gy RT + 36 Gy SRS & NR & $\begin{array}{l}\text { GBM: } 16 \\
\text { AA: } 33\end{array}$ \\
\hline Shrieve [16] & 78 & $\mathrm{RT}+\mathrm{SRS}$ & 1-yr OS: 88.5\% 2-yr OS: 35.9\% & 19.9 \\
\hline Floyd [17] & 20 & 40 Gy RT + 24 Gy SRS, temozolomide & NR & 13 \\
\hline Landy [18] & 23 & Estramustine + SRS & 2-yr OS: $38 \%$ & 16 \\
\hline Omuro [19] & 40 & $\begin{array}{l}6 \times 6 \text { Gy or } 6 \times 4 \text { Gy SRS + } \\
\text { temozolomide + bevacizumab }\end{array}$ & 1-yr OS: 93\% & 19 \\
\hline \multicolumn{5}{|c|}{$\begin{array}{l}\text { TABLE 1: Summary of Published Studies of SRS for the Treatment of Newly } \\
\text { Diagnosed Glioblastoma }\end{array}$} \\
\hline \multicolumn{5}{|c|}{$\begin{array}{l}\text { Abbreviations: AA: anaplastic astrocytoma; DSS: disease-specific survival; GBM: glioblastoma multiforme; KPS: Karnofsky } \\
\text { Performance Score; NR: data not reported; OS: overall survival; PFS: progression-free survival; RT: external beam radiation } \\
\text { therapy; SRS: stereotactic radiosurgery }\end{array}$} \\
\hline
\end{tabular}

A more limited number of small studies have suggested optimistic outcomes following SRS alone in patients with newly diagnosed GBM [20-22]. In aggregate, these data suggest a potential benefit (which obviously needs to be rigorously tested) of SRS with concurrent chemotherapy, preferably temozolomide, in newly diagnosed GBM with favorable prognostic factors, including an extensive resection with limited residual tumor volume, young age, and high Karnofsky performance status (KPS) [23]. Nonetheless, these studies are weakened by their small size and concerns, such as selection bias; therefore, in the absence of additional higherlevel data, at present SRS alone or as a boost following external beam radiation therapy is not considered a standard therapy in patients with newly diagnosed GBM.

One particular SRS approach, popularized under the term "leading-edge radiosurgery" as well as a variation of it, referred to as "border-zone radiosurgery" deserves specific mention. In 
these approaches, rather than defining the SRS target as a geometric contour of the enhancing abnormality or surgical bed only, an "edge" or "zone" predictive of the highest likelihood of harboring microscopic residual disease predictive of the likelihood of relapse is targeted, using advanced magnetic resonance imaging parameters [24]. Duma, et al. presented a 15-year follow-up in 109 newly diagnosed GBM patients, the majority of whom received upfront involved field radiotherapy and temozolomide, and "leading edge" SRS to a mean volume of $33.5 \mathrm{cc}$ (2.5 - $220 \mathrm{cc}$ range), with a median dose of $8 \mathrm{~Gy}$ at the 50\% isodose line [Duma, C: Front "leading edge" Gamma Knife radiosurgery for newly diagnosed GBM: a 15-year follow-up. Presented at the 17th International Leksell Gamma Knife Society Meeting, 2014, unpublished data]. The second, third, and fifth-year survival rates were 43,19 , and $12 \%$, respectively. The majority (97/109) of the patients were in the RTOG RPA Class IV, and an indirect comparison with separate radiotherapy alone $(n=150)$ and radiotherapy and temozolomide $(n=152)$ revealed a median survival of 13,16 , and 23 months, the latter representing the "leading edge" group.

With advances in technology, the concept of single fraction SRS has started to emerge in certain clinical situations into a hypofractionated approach, combining the principles of stereotaxy and fractionation. This approach, essentially a variant of SRS, has also been explored in the upfront management of GBM with several institutional reports and studies. One intriguing study in this context, by Omuro, et al., treated 40 newly diagnosed GBM patients on an in-house clinical trial with hypofractionated stereotactic radiotherapy (6 Gy x 6 to the contrast-enhancing region and 4 Gy x 6 to the FLAIR abnormality, using a simultaneous integrated boost approach) in combination with temozolomide and bevacizumab, with the latter being used primarily to control peritumoral and radiation-induced edema and vascular changes [19]. The one-year overall survival was 93\% and the median survival was 19 months. Similar to the prior RTOG trial, patients undergoing gross total resection fared better with a median survival of 26 months, compared to 16 months for patients with lesser resections. More intriguingly, the median overall survival for unmethylated patients was 22 months, compared to 18 months for methylated tumors. Most conventional non-SRS GBM studies combining temozolomide and radiotherapy describe median survival values of approximately 14 months for the unmethylated subgroup, suggesting that the therapeutic value of hypofractionation might be greatest in the MGMT unmethylated tumors, which are more likely to be mesenchymal and hypoxic [19].

Therefore, from the early era of RTOG 9305, where SRS was used without temozolomide, to the modern era of combination chemotherapy, and the recognition of molecular subtypes that could identify subgroups that could benefit from SRS, a careful and scientifically rigorous reevaluation of the role of this modality is warranted.

\section{SRS in recurrent GBM}

An alternative application of SRS is in patients with recurrent GBM that have progressed following the standard of care fractionated radiation therapy, plus temozolomide. A number of small prospective and retrospective series suggest that SRS may prolong survival in this setting, either alone or in combination with chemotherapy (Table 2) [25-35].

\begin{tabular}{|c|c|c|c|c|c|}
\hline Author & $\mathbf{N}$ & Treatment Schema & $\begin{array}{l}\text { Median Time to } \\
1^{\text {st }} \text { Recurrence } \\
\text { (Range) Months }\end{array}$ & $\begin{array}{l}\text { OS Rate After } \\
\text { SRS Salvage }\end{array}$ & $\begin{array}{l}\text { Median OS } \\
\text { (Range) Months }\end{array}$ \\
\hline Shrieve [25] & $\begin{array}{l}86 \text { tx with SRS } \\
\text { alone; } 32 \text { tx } \\
\text { with }\end{array}$ & 13 Gy (median) SRS & NR & $\begin{array}{l}\text { 1-yr (SRS pts): } \\
45 \% 2-y r \text { (SRS }\end{array}$ & 10.2 for SRS pts \\
\hline
\end{tabular}




\section{Cureus}

\begin{tabular}{|c|c|c|c|c|c|}
\hline & $\begin{array}{l}\text { brachytherapy } \\
\text { alone }\end{array}$ & & & pts) : $19 \%$ & \\
\hline $\begin{array}{l}\text { Vordermark } \\
{[26]}\end{array}$ & 19 & 20-30 Gy SRS & 19 (3-116) & $\begin{array}{l}1-y r: 26 \% 2-y r: \\
16 \%\end{array}$ & $9.3(1.9-77.6+)$ \\
\hline $\begin{array}{l}\text { Lederman } \\
\text { [27] }\end{array}$ & $\begin{array}{l}9 \text { SRS alone; } \\
14 \text { SRS + Taxol }\end{array}$ & $\begin{array}{l}\text { SRS alone: Mean dose } 19.2 \\
\text { Gy in } 1 \text { fraction SRS + } \\
\text { Taxol: Mean dose of } 24 \text { Gy } \\
\text { in } 4 \text { fractions }\end{array}$ & 11 & $\begin{array}{l}\text { 1-yr SRS alone: } \\
11 \% \quad 1-y r \text { SRS } \\
+ \text { Taxol: } 50 \%\end{array}$ & $\begin{array}{l}\text { SRS alone: } 6.3 \\
\text { SRS + Taxol: } \\
14.2\end{array}$ \\
\hline Combs [28] & 32 & 10-20 Gy (median 15 Gy) & $10(1-77)$ & $\begin{array}{l}6 \text { months: } 72 \% \\
1-y r: 38 \%\end{array}$ & 10 \\
\hline Fogh [29] & 147 & $\begin{array}{l}28-80 \text { Gy (median dose } 35 \\
\text { Gy in } 3.5 \text { Gy fractions) }\end{array}$ & $8(4-205)$ & NR & 11 \\
\hline $\begin{array}{l}\text { Maranzano } \\
{[30]}\end{array}$ & 22 & $\begin{array}{l}17 \text { Gy (median) SRS or } 30 \\
\text { Gy (median) fractionated } \\
\text { SRS }\end{array}$ & 9 & & 11 \\
\hline $\begin{array}{l}\text { Greenspoon } \\
{[31]}\end{array}$ & 31 & 25 - 30 Gy + temozolomide & NR & NR & 9 \\
\hline Hudes[32] & 20 & $\begin{array}{l}24 \text { Gy/3 fx } 30 \text { Gy/3 fx } 35 \\
\text { Gy/3.5 fx }\end{array}$ & $3.1(0.7-45.5)$ & 1-yr OS: $20 \%$ & 20 \\
\hline $\begin{array}{l}\text { Lederman } \\
\text { [33] }\end{array}$ & 88 & $\begin{array}{l}4 \text { weekly irradiation (median } \\
6 \text { Gy) after Paclitaxel }\end{array}$ & 6.5 & $\begin{array}{l}\text { 1-yr: 17\% 2-yr: } \\
3.4 \%\end{array}$ & 7 \\
\hline Cuneo [34] & $\begin{array}{l}\text { WHO Grade 3: } \\
\text { 16 WHO Grade } \\
\text { 4: } 33\end{array}$ & $\begin{array}{l}12.5-25 \text { (median 15) Gy SRS } \\
12.5-25 \text { Gy SRS + } \\
\text { bevacizumab }\end{array}$ & All pts: 20 & $\begin{array}{l}\text { WHO Grade 3, } \\
\text { 1-yr: } 22 \% \\
\text { WHO Grade 4, } \\
\text { 1-yr: } 50 \%\end{array}$ & $\begin{array}{l}\text { WHO Grade } 3 \\
\text { glioma: } 3.9 \\
\text { WHO Grade } 4 \\
\text { glioma: } 11.2\end{array}$ \\
\hline Minniti [35] & 54 & $\begin{array}{l}30 \text { Gy/6 fx SRS + } \\
\text { temozolomide }\end{array}$ & $\begin{array}{l}\text { Median time } \\
\text { between primary } \\
\text { RT and } \\
\text { reirradiation: } \\
15.5\end{array}$ & $\begin{array}{l}\text { 1-yr: 53\% 2-yr: } \\
10 \%\end{array}$ & 12.4 \\
\hline
\end{tabular}

\section{TABLE 2: Summary of Published Studies of SRS for Recurrent GBM}

Abbreviations: ANA: anaplastic astrocytoma; ANMO: anaplastic mixed oligoastrocytoma; fx: fraction; GBM: glioblastoma multiforme; Gy: Grey; RT: external beam radiation therapy; SRS: stereotactic radiosurgery; WHO: World Health Organization

In these studies, the median time from the initial course of radiation therapy to radiosurgery varied (range: 3-10 months) and overall survival from the time of reirradiation ranged from 7-16 months, which generally compares favorably to the anticipated survival in patients with recurrent GBM. In most situations, SRS is performed once in a patient's disease course; however, there is a case report of multiple rounds of SRS to different regions of recurrence in a patient with a prolonged survival [36]. 


\section{Cureus}

Recently, Larson, et al. reviewed the literature for recent studies describing the use of Gamma Knife radiosurgery for recurrent GBM and identified nine reports between 2005-2013 (Table 3)

[37]. The median overall survival ranged from 9-17.9 months from salvage SRS, and the median progression-free survival ranged from 4.6-14.9 months (Table 3) [38-46].

\begin{tabular}{|c|c|c|c|c|c|c|}
\hline Author & $\mathbf{N}$ & $\begin{array}{l}\text { Median } \\
\text { SRS Dose } \\
\text { (Range) Gy }\end{array}$ & $\begin{array}{l}\text { Time to } 1^{\text {st }} \\
\text { Recurrence } \\
\text { (Months) }\end{array}$ & $\begin{array}{l}\text { Median Survival From } \\
\text { Diagnosis (Months) }\end{array}$ & $\begin{array}{l}\text { Median Survival After } \\
\text { Treatment Months) }\end{array}$ & $\begin{array}{l}\text { Local } \\
\text { Tumor } \\
\text { Control }\end{array}$ \\
\hline Skeie [38] & $\begin{array}{l}32 \text { GK; } 26 \\
\text { reoperation; } 19 \\
\text { both } \\
\text { procedures }\end{array}$ & $12.2(8-20)$ & & $\begin{array}{l}51 \text { pts that recelved } \\
\text { GK: } 1926 \text { pts with } \\
\text { reoperation only: } 16\end{array}$ & $\begin{array}{l}51 \text { pts that recelved } \\
\text { GK: } 1226 \text { pts with } \\
\text { reoperation only: } 6\end{array}$ & \\
\hline Park [39] & $\begin{array}{l}11 \mathrm{GK}+\mathrm{BZ} ; 44 \\
\text { GK alone }\end{array}$ & $\begin{array}{l}16(13-18) \\
15(10-20)\end{array}$ & NR & 33.226 .7 & 17.912 .2 & NR NR \\
\hline Koga $[40]$ & $\begin{array}{l}9 \text { conventional } \\
\text { GK; } 9 \text { EF GK }\end{array}$ & 2020 & $\begin{array}{l}14.5 \\
\text { (median) } 12 \\
\text { (median) }\end{array}$ & 2421 & 10.59 & $\begin{array}{l}47 \% \\
93 \%\end{array}$ \\
\hline $\begin{array}{l}\text { Elliott } \\
\text { [41] }\end{array}$ & 16 & 16 & 7.9 (median) & 26.1 & 13 & NR \\
\hline $\begin{array}{l}\text { Pouratian } \\
\text { [42] }\end{array}$ & 26 & 26 & $N R$ & 17.4 & 9.4 & NR \\
\hline Kida [43] & 54 & 54 & NR & 27.0 & 14.0 & NR \\
\hline Kong [44] & 65 & 65 & 4.3 & 23.0 & 13 & NR \\
\hline $\begin{array}{l}\text { Kohshi } \\
\text { [45] }\end{array}$ & 11 & 11 & NR & 21.0 & 11 & NR \\
\hline $\begin{array}{l}\text { Hsieh } \\
{[46]}\end{array}$ & 26 & 26 & NR & 16.7 & 10 & NR \\
\hline
\end{tabular}

TABLE 3: Summary of Outcomes Following Salvage Gamma Knife SRS for Recurrent GBM

Abbreviations: BZ: Bevacizumab; EF: extended field; GK: Gamma Knife; GTR: gross tumor resection; NR: data not reported or not segregated for GBM patients

A challenge in interpreting these and other results is that many studies do not report details regarding the most relevant factors. For example, factors, such as initial radiation dose, the extent of initial and second surgical resections, tumor volume at the time of SRS, timing and use of chemotherapy, and the time between initial radiation therapy and retreatment have clear implications on patient outcomes but are variably reported [47]. In addition, many studies do not report on re-operation following SRS and whether the final pathology from that intervention revealed active tumor versus radiation necrosis. Finally, selection bias could also 
contribute to better than expected results in these reports. Nevertheless, in spite of all of these limitations, it appears that a small proportion of patients do live longer than expected and careful evaluation of the role of SRS in the recurrent setting is warranted. In this context, the "border zone" recurrent GBM trial recently initiated by the Gamma Knife Consortium represents a well-coordinated multi-institutional effort designed to prospectively and rigorously study this therapy [48]. Patients will be treated with "border-zone" SRS where magnetic resonance spectroscopy (MRS) will be used to guide the treatment volume in a single arm Phase II study. Patients will be treated with bevacizumab prior to SRS and then every 14 days until the time of tumor progression. The primary endpoint is a two-year overall survival.

Similar to the experience with newly diagnosed GBM, several small prospective and retrospective studies have evaluated the addition of bevacizumab to SRS in recurrent GBM. The results have been favorable with overall survival ranging from 12-15 months, one-year survival as high as 50\%, and lower rates of adverse radiation effects (range: 0-10\%) [34, 39, 49].

\section{Toxicity of SRS}

A concern with SRS for GBM in both the upfront and recurrent setting is the high rate of toxicity. Several studies have reported serious neurologic deficits, including hemiparesis, severe headache, somnolence, and vision loss following SRS [9, 16, 29, 34-35, 39, 49-53]. Rates of reoperation are high, ranging from $50-57 \%$, and reveal high rates of radiation necrosis (range: 10-38\%) [9, 16, 23, 54]. In addition, prolonged requirements for corticosteroids have been reported in a large percentage of patients $[9,55]$. See Table 4 for a summary of toxicities following SRS treatment of GBM. 


\section{Cureus}

\begin{tabular}{|c|c|c|c|}
\hline Author & $\mathbf{N}$ & Dose & Toxicity \\
\hline $\begin{array}{l}\text { Sarkaria } \\
\text { [9] }\end{array}$ & 115 & $\begin{array}{l}54-60 \text { Gy RT } \\
+10-20 \text { Gy } \\
\text { SRS }\end{array}$ & $\begin{array}{l}17 \text { patients with radiation necrosis, } 1 \text { patient with hemiparesis. } 47 \% \\
\text { required prolonged steroid use. One patient with double vision and } \\
\text { hydrocephalus requiring ventricular shunt. }\end{array}$ \\
\hline $\begin{array}{l}\text { Schrieve } \\
{[16]}\end{array}$ & 78 & & $\begin{array}{l}50 \% \text { had reoperation for symptomatic necrosis or recurrent tumor. } \\
\text { Rate of reoperation at } 24 \text { months after SRS was } 54.8 \% \text {. }\end{array}$ \\
\hline Fogh [29] & 147 & $\begin{array}{l}\text { Median } 35 \\
\text { Gy/3.5 Gy fx }\end{array}$ & One late Grade 3 CNS toxicity 4 months after hypofractionated SRS. \\
\hline $\begin{array}{l}\text { Cuneo } \\
{[34]}\end{array}$ & $\begin{array}{l}21 \text { SRS } 42 \\
\text { SRS + } \\
\text { bevacizumab }\end{array}$ & $\begin{array}{l}12.5-25 \text { Gy } \\
12.5-25 \text { Gy + } \\
\text { bevacizumab }\end{array}$ & $\begin{array}{l}14 \% \text { Grade } 3,5 \% \text { Grade } 4,19 \% \text { radionecrosis, } 29 \% \text { worsening of } \\
\text { neurologic symptoms, } 19 \% \text { increase seizures } 10 \% \text { Grade } 3,5 \% \\
\text { radionecrosis, } 24 \% \text { worsening of neurologic symptoms, } 21 \% \text { increase } \\
\text { seizures }\end{array}$ \\
\hline $\begin{array}{l}\text { Minniti } \\
{[35]}\end{array}$ & 54 & $\begin{array}{l}30 \mathrm{~Gy} / 5 \mathrm{fx}+ \\
\text { temozolomide }\end{array}$ & $\begin{array}{l}7 \% \text { Grade } 3 \text { neurologic deterioration with radiation-induced necrosis; } 7 \\
\text { patients with Grade } 3 \text { lymphopenia, } 3 \text { patients with Grade } 4 \\
\text { lymphocytopenia, } 2 \text { patients with Grade } 3 \text { thrombocytopenia, }\end{array}$ \\
\hline Park [39] & 11 & $\begin{array}{l}\text { 13-18 Gy + } \\
\text { bevacizumab }\end{array}$ & One Grade 3 toxicity and 1 major adverse radiation effect. \\
\hline Gutin [49] & $\begin{array}{l}25(20 \mathrm{GBM} \\
\text { and } 5 \mathrm{AA})\end{array}$ & $\begin{array}{l}30 \text { Gy/5 fx }+ \\
\text { bevacizumab }\end{array}$ & $\begin{array}{l}8 \% \text { Grade } 3 \text { leukopenia, } 8 \% \text { Grade } 3 \text { neutropenia, } 28 \% \text { Grade } 3 \\
\text { lymphopenia, } 8 \% \text { Grade } 3 \text { thrombocytopenia, } 12 \% \text { Grade } 3 \text { anemia, } 4 \% \\
\text { Grade } 3 \text { fatigue, } 4 \% \text { Grade } 3 \text { hypertension, } 4 \% \text { Grade } 3 \text { CNS } \\
\text { hemorrhage, } 8 \% \text { Grade } 4 \text { lymphopenia, } 4 \% \text { Grade } 4 \text { thrombocytopenia, } \\
4 \% \text { Grade } 4 \text { bowel perforation, } 4 \% \text { Grade } 4 \text { wound healing } \\
\text { complication, } 4 \% \text { Grade } 4 \text { gastrointestinal bleeding }\end{array}$ \\
\hline $\begin{array}{l}\text { Lederman } \\
{[50]}\end{array}$ & 14 & $\begin{array}{l}4.5-9 \text { Gy x } 4 \\
\text { fx (median } 6 \\
\text { Gy } \times 4)+ \\
\text { Taxol }\end{array}$ & $\begin{array}{l}4 \text { patients had re-operation, } 3 \text { of } 4 \text { had radionecrosis only, } 1 \text { of } 4 \text { had } \\
\text { radionecrosis and tumor detected }\end{array}$ \\
\hline Niyazi [51] & $\begin{array}{l}20 \text { SRS alone } \\
10 \text { SRS + } \\
\text { bevacizumab }\end{array}$ & $\begin{array}{l}36 \text { Gy/18 fx } \\
+/- \\
\text { bevacizumab }\end{array}$ & $\begin{array}{l}1 \text { Grade } 2 \text { fatigue, } 1 \text { Grade } 2 \text { hypertension, } 1 \text { Grade } 3 \text { deep vein } \\
\text { thrombosis, } 1 \text { Grade } 4 \text { wound healing complication }\end{array}$ \\
\hline $\begin{array}{l}\text { Ogura } \\
{[52]}\end{array}$ & 30 & $\begin{array}{l}22.5-35 \mathrm{~Gy} / 5 \\
\mathrm{fx}\end{array}$ & 2 patients with Grade 3 radionecrosis \\
\hline $\begin{array}{l}\text { Cabrera } \\
{[53]}\end{array}$ & 15 & $\begin{array}{l}18 \text { or } 24 \text { Gy/1 } \\
\text { fx or } 25 / 5 \mathrm{fx}+ \\
\text { bevacizumab }\end{array}$ & $\begin{array}{l}1 \text { Grade } 3 \text { severe headache, } 2 \text { Grade } 2 \text { CNS toxicities. No Grade } 4 \text { or } 5 \\
\text { events. }\end{array}$ \\
\hline
\end{tabular}

\section{TABLE 4: Summary of Toxicities for SRS Treatment of GBM}

Abbreviations: AA: anaplastic astrocytoma; CNS: central nervous system; fx: fraction; Gy: Grey; SRS: stereotactic radiosurgery

\section{SRS, plus bevacizumab, to modulate toxicity}


To minimize some of these toxicities, a number of studies, as mentioned above, have combined SRS for GBM with bevacizumab. Bevacizumab is a monoclonal antibody that inhibits vascular endothelial growth factor-A, thereby impeding angiogenesis. While a large randomized prospective study did not find a survival benefit with the addition of bevacizumab to the standard of care therapy in patients with newly diagnosed GBM, it is hypothesized that the drug's impact on vascular permeability may reduce the risk of SRS-associated edema and necrosis [56]. In fact, a number of small studies have demonstrated that bevacizumab can, in fact, be utilized to treat radiation necrosis, and as mentioned above, when bevacizumab is added to SRS in recurrent GBM, the rates of adverse radiation effects are lower (range: 0-10\%) $[34,39,49,55]$. Similar results were reported in patients receiving bevacizumab with reirradiation using conventional fractionation [51]. In the newly diagnosed setting, in the abovedescribed Memorial Sloan Kettering Cancer Center study utilizing bevacizumab for newly diagnosed GBM patients treated with hypofractionated stereotactic radiotherapy, there was no reported pseudoprogression with an encouraging quality of life and neuropsychological evaluations. Nonetheless, bevacizumab is associated with its own substantial toxicities, including intratumoral hemorrhage and bowel dehiscence [49]. While the results are favorable, further prospective investigations are necessary before the treatment paradigm can be broadly applied in clinical practice.

\section{Patient selection}

The role of SRS in patients with glioblastoma remains controversial. At present, there are minimal data to support its unselected use in the newly diagnosed setting, although further investigation of new paradigms, such as the use of concurrent bevacizumab with SRS and temozolomide, remains warranted. Similarly, there are no consensus guidelines to direct practice in the recurrent setting. However, most studies have enrolled patients with limited disease measuring $<4-5 \mathrm{~cm}$ in maximal diameter and a minimum of 5-10 millimeters from the tumor to dose-limiting critical structures, such as the optic apparatus. Care should be utilized in patients with gross disease involving the brainstem and patients with subependymal spread of their disease, who are less likely to benefit from the procedure. The ideal candidates for SRS in recurrent GBM would have a favorable performance status, good response to initial chemoradiation therapy, a relatively prolonged interval to recurrence, and limited volume, circumscribed recurrence. At least one report suggests that MRS could be utilized to select appropriate candidates, and PET imaging with novel tracers could also have a role in this situation. It should be noted that the radiographic appearance of pseudoprogression and necrosis mirrors tumor progression, which needs to be ruled out prior to proceeding with SRS.

\section{SRS technique}

The frame-based approach is the most common technique utilized for single fraction radiosurgery and affords unparalleled accuracy. Fractionated delivery is often performed with the patient immobilized supine in an aquaplast mask. A contrast-enhanced high-resolution thin slice (e.g. $1 \mathrm{~mm}$ ) MRI should be considered the requisite baseline image for contouring purposes and is often co-registered to a simulation computerized tomography (CT), which, if performed, should similarly also be a thin-slice dataset. Many institutions define the gross tumor volume (GTV) as the region of contrast enhancement on T1 post-gadolinium MRI, with minimal or no margin. In other words, clinical target volume (CTV) = GTV; for framed systems, the planning target volume (PTV) = CTV, but a set-up margin for PTV expansion is often used for mask-based systems. However, retrospective data, at least with the fractionated approach, suggest improved local control when FLAIR abnormalities are included in the target volume or when larger margins of 0.5 to $1 \mathrm{~cm}$ are utilized [57-58]. These studies suggest that the extended treatment volumes have acceptable toxicity and a benefit in terms of both local tumor control and regional tumor progression. It remains unclear whether this will translate into a survival benefit, but the concept, potentially with concurrent bevacizumab, is worthy of further 
investigation.

There is wide variability in dose and fractionation schedules between institutions and studies. In patients with disease amenable to treatment with a single fraction, the doses outlined in RTOG 9005 are reasonable. According to this study, the maximum tolerated single fraction dose for patients with tumors $\leqslant 20 \mathrm{~mm}$ is $24 \mathrm{~Gy}, 21-30 \mathrm{~mm}$ is $18 \mathrm{~Gy}$, and $31-40 \mathrm{~mm}$ is $15 \mathrm{~Gy}$ [59]. In patients with larger tumors or where there is concern that edema might lead to worsening neurologic deficits, fractionation is advisable. Reasonable fractionation schemes include 25-35 Gy in five fractions [31, 53]. A dose response has been noted, with improved local control with higher radiation doses, but the optimal schedule remains to be determined [32].

The dose-limiting structures are generally the optic apparatus and brainstem. Although many institutions are more conservative in their dosing, for patients without prior radiation receiving a single fraction treatment, the maximum point dose to the optic apparatus according to AAPM Task Group 101 (TG-101) is 10 Gy and to the brainstem is 15 Gy [60]. In patients receiving five fractions, TG-101 allows a maximum point dose to the optic apparatus of 25 Gy and 30-31 Gy to the brainstem [60]. In the retreatment setting, the constraints for these structures should be modified to account for the previous dose.

\section{Future directions}

There are a variety of critical questions that remain regarding the role of SRS in GBM. As discussed above, the optimal fractionation schedule and target volumes remain uncertain. Innovative imaging technologies to more definitively delineate the region of the active tumor may allow improved outcomes while potentially reducing toxicity. For example, a recent Phase II study utilizing MRS for SRS target definition revealed a significantly improved median overall survival compared to a historical control [60]. Techniques that actively identify infiltrative tumor margins, as opposed to iso-volumetric expansions, might prove to be useful as suggested by the "leading-edge" and "border-zone" concepts.

Furthermore, the potential role of bevacizumab or other systemic agents to mitigate the toxicities of SRS will be an important avenue of future study. Similarly, case reports have suggested an abscopal effect in patients receiving immune checkpoint inhibitors with radiation therapy, and a case report from a patient with brain metastases from melanoma suggested complete resolution on follow-up imaging [62-63]. While prospective data evaluating this concept in patients with GBM do not exist currently, these combination therapies may provide an intriguing approach to treating this tumor.

\section{Conclusions}

GBM is one of the most aggressive human malignancies, which remains almost universally fatal in spite of aggressive multimodality therapy including surgery, radiation therapy, and chemotherapy. The predominant pattern of recurrence is local, and SRS represents a technique to precisely deliver high doses of radiation while limiting exposure to the adjacent critical structures, such as the brainstem and optic chiasm. At present, the technique is most appropriate in patients with focally recurrent GBM. Preliminary studies utilizing bevacizumab in combination with SRS suggest that it may help to mitigate SRS toxicity in this setting. Future investigations will be critical in further evaluating this possibility and determining the optimal dose and fractionation schedules.

\section{Additional Information}

\section{Disclosures}


Conflicts of interest: In compliance with the ICMJE uniform disclosure form, all authors declare the following: Payment/services info: All authors have declared that no financial support was received from any organization for the submitted work. Financial relationships: Kristin Redmond declare(s) a grant from Elekta. Member of Elekta Oligometastasis Consortium. Minesh Mehta declare(s) personal fees from Elekta. Consultant. Minesh Mehta declare(s) personal fees from Phillips. Consultant. Minesh Mehta declare(s) stock/stock options from Pharmacyclics. Board of Directors. Minesh Mehta declare(s) personal fees from GenentechRoche. Consultant. Minesh Mehta declare(s) personal fees from Novelos. Consultant. Minesh Mehta declare(s) personal fees from Novocure. Consultant. Minesh Mehta declare(s) personal fees from Abbvie. Consultant. Other relationships: All authors have declared that there are no other relationships or activities that could appear to have influenced the submitted work.

\section{References}

1. SEER Cancer Statistics Factsheets: Brain and Other Nervous System Cancer . (2014). Accessed: August 15, 2015: http://seer.cancer.gov/statfacts/html/brain.html.

2. Stupp R, Mason WP, van den Bent MJ, Weller M, Fisher B, Taphoorn MJ, Belanger K, Brandes AA, Marosi C, Bogdahn U, Curschmann J, Janzer RC, Ludwin SK, Gorlia T, Allgeier A, Lacombe D, Cairncross JG, Eisenhauer E, Mirimanoff RO, European Organisation for Research and Treatment of Cancer Brain Tumors Radiotherapy Group; National Cancer Institute of Canada Clinical Trials Group: Radiotherapy plus concomitant and adjuvant temozolomide for glioblastoma. N Engl J Med. 2005, 352:987-96. 10.1056/NEJMoa043330

3. Stupp R, Hegi ME, Mason WP, van den Bent MJ, Taphoorn MJ, Janzer RC, Ludwin SK, Allgeier A, Fisher B, Belanger K, Hau P, Brandes AA, Gijtenbeek J, Marosi C, Vecht CJ, Mokhtari K, Wesseling P, Villa S, Eisenhauer E, Gorlia T, Weller M, Lacombe D, Cairncross JG, Mirimanoff RO, European Organisation for Research and Treatment of Cancer Brain Tumors Radiation Oncology Group and National Cancer Institute of Canada Clinical Trials Group: Effects of radiotherapy with concomitant and adjuvant temozolomide versus radiotherapy alone on survival in glioblastoma in a randomised phase III study: 5-year analysis of the EORTC-NCIC trial. Lancet Oncol. 2009, 10:459-66. 10.1016/S1470-2045(09)70025-7

4. Tsao MN, Mehta MP, Whelan TJ, Morris DE, Hayman JA, Flickinger JC, Mills M, Rogers CL, Souhami L: The American Society for Therapeutic Radiology and Oncology (ASTRO) evidence-based review of the role of radiosurgery for malignant glioma. Int J Radiat Oncol Biol Phys. 2005, 63:47-55. 10.1016/j.ijrobp.2005.05.024

5. Wallner KE, Galicich JH, Krol G, Arbit E, Malkin MG: Patterns of failure following treatment for glioblastoma multiforme and anaplastic astrocytoma. Int J Radiat Oncol Biol Phys. 1989, 16:1405-9. 10.1016/0360-3016(89)90941-3

6. Souhami L, Seiferheld W, Brachman D, Podgorsak EB, Werner-Wasik M, Lustig R, Schultz CJ, Sause W, Okunieff P, Buckner J, Zamorano L, Mehta MP, Curran WJ, Jr: Randomized comparison of stereotactic radiosurgery followed by conventional radiotherapy with carmustine to conventional radiotherapy with carmustine for patients with glioblastoma multiforme: report of Radiation Therapy Oncology Group 93-05 protocol. Int J Radiat Oncol Biol Phys. 2004, 60:853-60. 10.1016/j.ijrobp.2004.04.011

7. Chuang CF, Chan AA, Larson D, Verhey LJ, McDermott M, Nelson SJ, Pirzkall A: Potential value of MR spectroscopic imaging for the radiosurgical management of patients with recurrent high-grade gliomas. Technol Cancer Res Treat. 2007, 6:375-82.

10.1177/153303460700600502

8. Sheehan JP, Xu Z, Popp B, Kowalski L, Schlesinger D: Inhibition of glioblastoma and enhancement of survival via the use of mibefradil in conjunction with radiosurgery. J Neurosurg. 2013, 118:830-37. 10.3171/2012.11.jns121087

9. Sarkaria JN, Mehta MP, Loeffler JS, Buatti JM, Chappell RJ, Levin AB, Alexander E, 3rd, Friedman WA, Kinsella TJ: Radiosurgery in the initial management of malignant gliomas: survival comparison with the RTOG recursive partitioning analysis. Radiation Therapy Oncology Group. Int J Radiat Oncol Biol Phys. 1995, 32:931-41. 10.1016/0360-3016(94)00621Q

10. Gannett D, Stea B, Lulu B, Adair T, Verdi C, Hamilton A: Stereotactic radiosurgery as an adjunct to surgery and external beam radiotherapy in the treatment of patients with 
malignant gliomas. Int J Radiat Oncol Biol Phys. 1995, 33:461-68. 10.1016/0360-

3016(95)00087-F

11. Masciopinto JE, Levin AB, Mehta MP, Rhode BS: Stereotactic radiosurgery for glioblastoma: a final report of 31 patients. J Neurosurg. 1995, 82:530-35. 10.3171/jns.1995.82.4.0530

12. Mehta MP, Masciopinto J, Rozental J, Levin A, Chappell R, Bastin K, Miles J, Turski P, Kubsad $\mathrm{S}$, Mackie T: Stereotactic radiosurgery for glioblastoma multiforme: report of a prospective study evaluating prognostic factors and analyzing long-term survival advantage. Int J Radiat Oncol Biol Phys. 1994, 30:541-49. 10.1016/0360-3016(92)90939-F

13. Nwokedi EC, DiBiase SJ, Jabbour S, Herman J, Amin P, Chin LS: Gamma Knife stereotactic radiosurgery for patients with glioblastoma multiforme. Neurosurgery. 2002, 50:41-46. 10.1097/00006123-200201000-00009

14. Balducci M, Apicella G, Manfrida S, Mangiola A, Fiorentino A, Azario L, D'Agostino GR, Frascino V, Dinapoli N, Mantini G, Albanese A, de Bonis P, Chiesa S, Valentini V, Anile C, Cellini N: Single-arm phase II study of conformal radiation therapy and temozolomide plus fractionated stereotactic conformal boost in high-grade gliomas: final report. Strahlenther Onkol. 2010, 186:558-64. 10.1007/s00066-010-2101-X

15. Cardinale RM, Schmidt-Ullrich RK, Benedict SH, Zwicker RD, Han DC, Broaddus WC: Accelerated radiotherapy regimen for malignant gliomas using stereotactic concomitant boosts for dose escalation. Radiat Oncol Investig. 1998, 6:175-81. 10.1002/(SICI)15206823(1998)6:4<175::AID-ROI5>3.0.CO;2-V

16. Shrieve DC, Alexander E, 3rd, Black PM, Wen PY, Fine HA, Kooy HM, Loeffler JS: Treatment of patients with primary glioblastoma multiforme with standard postoperative radiotherapy and radiosurgical boost: prognostic factors and long-term outcome. J Neurosurg. 1999, 90:72-77. 10.3171/jns.1999.90.1.0072

17. Floyd SR, Kasper EM, Uhlmann EJ, Fonkem E, Wong ET, Mahadevan A: Hypofractionated Radiotherapy and Stereotactic Boost with Concurrent and Adjuvant Temozolamide for Glioblastoma in Good Performance Status Elderly Patients - Early Results of a Phase II Trial. Front Oncol. 2012, 2:122. 10.3389/fonc.2012.00122

18. Landy H, Markoe A, Potter P, Lasalle G, Marini A, Savaraj N, Reis I, Heros D, Wangpaichitr M, Feun L: Pilot study of estramustine added to radiosurgery and radiotherapy for treatment of high grade glioma. J Neurooncol. 2004, 67:215-20. 10.1023/B:NEON.0000021825.41221.b5

19. Omuro A, Beal K, Gutin P, Karimi S, Correa DD, Kaley TJ, DeAngelis LM, Chan TA, Gavrilovic IT, Nolan C, Hormigo A, Lassman AB, Mellinghoff I, Grommes C, Reiner AS, Panageas KS, Baser RE, Tabar V, Pentsova E, Sanchez J, Barradas-Panchal R, Zhang J, Faivre G, Brennan CW, Abrey LE, Huse JT: Phase II Study of Bevacizumab, Temozolomide, and Hypofractionated Stereotactic Radiotherapy for Newly Diagnosed Glioblastoma. Clin Cancer Res. 2014, 20:502331. 10.1158/1078-0432.CCR-14-0822

20. Landy HJ, Schwade JG, Houdek PV, Markoe AM, Feun L: Long-term follow-up of gliomas treated with fractionated stereotactic irradiation. Acta Neurochir Suppl (Wien). 1994, 62:6771. 10.1007/978-3-7091-9371-6_14

21. Larson DA, Gutin PH, McDermott M, Lamborn K, Sneed PK, Wara WM, Flickinger JC, Kondziolka D, Lunsford LD, Hudgins WR, Friehs GM, Haselsberger K, Leber K, Pendl G, Chung SS, Coffey RJ, Dinapoli R, Shaw EG, Vermeulen S, Young RF, Hirato M, Inoue HK, Ohye C, Shibazaki T: Gamma knife for glioma: selection factors and survival . Int J Radiat Oncol Biol Phys. 1996, 36:1045-53. 10.1016/S0360-3016(96)00427-0

22. Shirazi HA, Grimm S, Raizer J, Mehta MP: Combined modality approaches in the management of adult glioblastoma. Front Oncol. 2011, 1:36. 10.3389/fonc.2011.00036

23. Sheehan J: Stereotactic radiosurgery for glioblastoma--time to revisit this approach . World Neurosurg. 2012, 78:592-93. 10.1016/j.wneu.2012.05.023

24. Border Zone Stereotactic Radiosurgery With Bevacizumab in Patients with Glioblastoma Multiforme. (2014). Accessed: December 1, 2015: https://clinicaltrials.gov/ct2/show/NCT02120287.

25. Shrieve DC, Alexander E, 3rd, Wen PY, Fine HA, Kooy HM, Black PM, Loeffler JS: Comparison of stereotactic radiosurgery and brachytherapy in the treatment of recurrent glioblastoma multiforme. Neurosurgery. 1995, 36:275-82. 10.1227/00006123-199502000-00006

26. Vordermark D, Kolbl O, Ruprecht K, Vince GH, Bratengeier K, Flentje M: Hypofractionated stereotactic re-irradiation: treatment option in recurrent malignant glioma. BMC Cancer. 2005, 5:55. 10.1186/1471-2407-5-55 
27. Lederman G, Arbit E, Odaimi M, Wertheim S, Lombardi E: Recurrent glioblastoma multiforme: potential benefits using fractionated stereotactic radiotherapy and concurrent taxol. Stereotact Funct Neurosurg. 1997, 69:162-74. 10.1159/000099870

28. Combs SE, Widmer V, Thilmann C, Hof H, Debus J, Schulz-Ertner D: Stereotactic radiosurgery (SRS): treatment option for recurrent glioblastoma multiforme (GBM). Cancer. 2005, 104:2168-73. 10.1002/cncr.21429

29. Fogh SE, Andrews DW, Glass J, Curran W, Glass C, Champ C, Evans JJ, Hyslop T, Pequignot E, Downes B, Comber E, Maltenfort M, Dicker AP, Werner-Wasik M: Hypofractionated stereotactic radiation therapy: an effective therapy for recurrent high-grade gliomas. J Clin Oncol. 2010, 28:3048-53. 10.1200/JCO.2009.25.6941

30. Maranzano E, Anselmo P, Casale M, Trippa F, Carletti S, Principi M, Loreti F, Italiani M, Caserta C, Giorgi C: Treatment of recurrent glioblastoma with stereotactic radiotherapy: longterm results of a mono-institutional trial. Tumori. 2011, 97:56-61.

31. Greenspoon JN, Sharieff W, Hirte H, Overholt A, Devillers R, Gunnarsson T, Whitton A: Fractionated stereotactic radiosurgery with concurrent temozolomide chemotherapy for locally recurrent glioblastoma multiforme: a prospective cohort study. Onco Targets Ther. 2014, 7:485-90. 10.2147/OTT.S60358

32. Hudes RS, Corn BW, Werner-Wasik M, Andrews D, Rosenstock J, Thoron L, Downes B, Curran WJ, Ir: A phase I dose escalation study of hypofractionated stereotactic radiotherapy as salvage therapy for persistent or recurrent malignant glioma. Int J Radiat Oncol Biol Phys. 1999, 43:293-98. 10.1016/S0360-3016(98)00416-7

33. Lederman G, Wronski M, Arbit E, Odaimi M, Wertheim S, Lombardi E, Wrzolek M: Treatment of recurrent glioblastoma multiforme using fractionated stereotactic radiosurgery and concurrent paclitaxel. Am J Clin Oncol. 2000, 23:155-59. 10.1097/00000421-200004000-00010

34. Cuneo KC, Vredenburgh JJ, Sampson JH, Reardon DA, Desjardins A, Peters KB, Friedman HS, Willett CG, Kirkpatrick JP: Safety and efficacy of stereotactic radiosurgery and adjuvant bevacizumab in patients with recurrent malignant gliomas. Int J Radiat Oncol Biol Phys. 2012, 82:2018-24. 10.1016/j.ijrobp.2010.12.074

35. Minniti G, Scaringi C, De Sanctis V, Lanzetta G, Falco T, Di Stefano D, Esposito V, Enrici RM: Hypofractionated stereotactic radiotherapy and continuous low-dose temozolomide in patients with recurrent or progressive malignant gliomas. J Neurooncol. 2013, 111:187-94. 10.1007/s11060-012-0999-9

36. Thumma SR, Elaimy AL, Daines N, Mackay AR, Lamoreaux WT, Fairbanks RK, Demakas JJ, Cooke BS, Lee CM: Long-term survival after gamma knife radiosurgery in a case of recurrent glioblastoma multiforme: a case report and review of the literature. Case Rep Med. 2012, 2012:545492. 10.1155/2012/545492

37. Larson EW, Peterson HE, Lamoreaux WT, MacKay AR, Fairbanks RK, Call JA, Carlson JD, Ling BC, Demakas JJ, Cooke BS, Lee CM: Clinical outcomes following salvage Gamma Knife radiosurgery for recurrent glioblastoma. World J Clin Oncol. 2014, 5:142-48. 10.5306/wjco.v5.i2.142

38. Skeie BS, Enger PO, Brogger J, Ganz JC, Thorsen F, Heggdal JI, Pedersen PH: Gamma Knife surgery versus reoperation for recurrent glioblastoma multiforme. World Neurosurg. 2012, 78:658-69. 10.1016/j.wneu.2012.03.024

39. Park KJ, Kano H, Iyer A, Liu X, Niranjan A, Flickinger JC, Lieberman FS, Lunsford LD, Kondziolka D: Salvage Gamma Knife stereotactic radiosurgery followed by bevacizumab for recurrent glioblastoma multiforme: a case-control study. J Neurooncol. 2012, 107:323-33. 10.1007/s11060-011-0744-9

40. Koga T, Maruyama K, Tanaka M, Ino Y, Saito N, Nakagawa K, Shibahara J, Todo T: Extended field stereotactic radiosurgery for recurrent glioblastoma. Cancer. 2012, 118:4193-200. 10.1002/cncr.27372

41. Elliott RE, Parker EC, Rush SC, Kalhorn SP, Moshel YA, Narayana A, Donahue B, Golfinos JG: Efficacy of gamma knife radiosurgery for small-volume recurrent malignant gliomas after initial radical resection. World Neurosurg. 2011, 76:128-40. 10.1016/j.wneu.2010.12.053

42. Pouratian N, Crowley RW, Sherman JH, Jagannathan J, Sheehan JP: Gamma Knife radiosurgery after radiation therapy as an adjunctive treatment for glioblastoma. J Neurooncol. 2009, 94:409-18. 10.1007/s11060-009-9873-9

43. Kida Y, Yoshimoto M, Hasegawa T: Radiosurgery for Intracranial Gliomas. Japanese Experience with Gamma Knife Radiosurgery. Yamamoto M (ed): Karger, Basel; 20090. 22:122- 


\section{8. $10.1159 / 000163336$}

44. Kong DS, Lee JI, Park K, Kim JH, Lim DH, Nam DH: Efficacy of stereotactic radiosurgery as a salvage treatment for recurrent malignant gliomas. Cancer. 2008, 112:2046-51. 10.1002/cncr.23402

45. Kohshi K, Yamamoto H, Nakahara A, Katoh T, Takagi M: Fractionated stereotactic radiotherapy using gamma unit after hyperbaric oxygenation on recurrent high-grade gliomas. J Neurooncol. 2007, 82:297-303. 10.1007/s11060-006-9283-1

46. Hsieh PC, Chandler JP, Bhangoo S, Panagiotopoulos K, Kalapurakal JA, Marymont MH, Cozzens JW, Levy RM, Salehi S: Adjuvant gamma knife stereotactic radiosurgery at the time of tumor progression potentially improves survival for patients with glioblastoma multiforme. Neurosurgery. 2005, 57:684-92. 10.1227/01.NEU.0000175550.96901.A3

47. Murovic JA, Chang SD: Outcomes after stereotactic radiosurgery and various adjuvant treatments for recurrent glioblastoma multiforme: a current literature review and comparison of multiple factors that impact outcome. World Neurosurg. 2012, 78:588-91.

10.1016/j.wneu.2012.06.005

48. Multicenter Phase II Study of Border Zone Stereotactic Radiosurgery With Bevacizumab in Patients With Recurrent or Progressive Glioblastoma Multiforme. (2014). Accessed: September 15, 2015: http://clinicaltrialsfeeds.org/clinical-trials/show/NCT02120287.

49. Gutin PH, Iwamoto FM, Beal K, Mohile NA, Karimi S, Hou BL, Lymberis S, Yamada Y, Chang J, Abrey LE: Safety and efficacy of bevacizumab with hypofractionated stereotactic irradiation for recurrent malignant gliomas. Int J Radiat Oncol Biol Phys. 2009, 75:156-63.

10.1016/j.ijrobp.2008.10.043

50. Lederman G, Arbit E, Odaimi M, Lombardi E, Wrzolek M, Wronski M: Fractionated stereotactic radiosurgery and concurrent taxol in recurrent glioblastoma multiforme: a preliminary report. Int J Radiat Oncol Biol Phys. 1998, 40:661-66. 10.1016/S0360-3016(97)00843-2

51. Niyazi M, Ganswindt U, Schwarz SB, Kreth FW, Tonn JC, Geisler J, la Fougere C, Ertl L, Linn J, Siefert A, Belka C: Irradiation and bevacizumab in high-grade glioma retreatment settings . Int J Radiat Oncol Biol Phys. 2012, 82:67-76. 10.1016/j.ijrobp.2010.09.002

52. Ogura K, Mizowaki T, Arakawa Y, Sakanaka K, Miyamoto S, Hiraoka M: Efficacy of salvage stereotactic radiotherapy for recurrent glioma: impact of tumor morphology and method of target delineation on local control. Cancer Med. 2013, 2:942-49. 10.1002/cam4.154

53. Cabrera AR, Cuneo KC, Desjardins A, Sampson JH, McSherry F, Herndon JE, 2nd, Peters KB, Allen K, Hoang JK, Chang Z, Craciunescu O, Vredenburgh JJ, Friedman HS, Kirkpatrick JP: Concurrent stereotactic radiosurgery and bevacizumab in recurrent malignant gliomas: a prospective trial. Int J Radiat Oncol Biol Phys. 2013, 86:873-79. 10.1016/j.ijrobp.2013.04.029

54. Regine WF, Patchell RA, Strottmann JM, Meigooni A, Sanders M, Young AB: Preliminary report of a phase I study of combined fractionated stereotactic radiosurgery and conventional external beam radiation therapy for unfavorable gliomas. Int J Radiat Oncol Biol Phys. 2000, 48:421-26. 10.1016/S0360-3016(00)00688-X

55. Cabrera AR, Cuneo KC, Vredenburgh JJ, Sampson JH, Kirkpatrick JP: Stereotactic radiosurgery and bevacizumab for recurrent glioblastoma multiforme. J Natl Compr Canc Netw. 2012, 10:695-99.

56. Gilbert MR, Dignam JJ, Armstrong TS, Wefel JS, Blumenthal DT, Vogelbaum MA, Colman H, Chakravarti A, Pugh S, Won M, Jeraj R, Brown PD, Jaeckle KA, Schiff D, Stieber VW, Brachman DG, Werner-Wasik M, Tremont-Lukats IW, Sulman EP, Aldape KD, Curran WJ, Jr., Mehta MP: A randomized trial of bevacizumab for newly diagnosed glioblastoma . N Engl J Med. 2014, 370:699-708. 10.1056/NEJMoa1308573

57. Koga T, Saito N: Efficacy and limitations of stereotactic radiosurgery in the treatment of glioblastoma. Neurol Med Chir (Tokyo). 2012, 52:548-52. 10.2176/nmc.52.548

58. Kim EY, Yechieli R, Kim JK, Mikkelsen T, Kalkanis SN, Rock J, Rosenblum M, Ryu S: Patterns of failure after radiosurgery to two different target volumes of enhancing lesions with and without FLAIR abnormalities in recurrent glioblastoma multiforme. J Neurooncol. 2014, 116:291-97. 10.1007/s11060-013-1290-4

59. Shaw E, Scott C, Souhami L, Dinapoli R, Kline R, Loeffler J, Farnan N: Single dose radiosurgical treatment of recurrent previously irradiated primary brain tumors and brain metastases: final report of RTOG protocol 90-05. Int J Radiat Oncol Biol Phys. 2000, 47:29198. 10.1016/S0360-3016(99)00507-6

60. Benedict SH, Yenice KM, Followill D, Galvin JM, Hinson W, Kavanagh B, Keall P, Lovelock M, 


\section{Cureus}

Meeks S, Papiez L, Purdie T, Sadagopan R, Schell MC, Salter B, Schlesinger DJ, Shiu AS, Solberg T, Song DY, Stieber V, Timmerman R, Tome WA, Verellen D, Wang L, Yin FF:

Stereotactic body radiation therapy: the report of AAPM Task Group 101 . Med Phys. 2010, 37:4078-4101. 10.1118/1.3438081

61. Einstein DB, Wessels B, Bangert B, Fu P, Nelson AD, Cohen M, Sagar S, Lewin J, Sloan A, Zheng Y, Williams J, Colussi V, Vinkler R, Maciunas R: Phase II trial of radiosurgery to magnetic resonance spectroscopy-defined high-risk tumor volumes in patients with glioblastoma multiforme. Int J Radiat Oncol Biol Phys. 2012, 84:668-74. 10.1016/j.ijrobp.2012.01.020

62. Stamell EF, Wolchok JD, Gnjatic S, Lee NY, Brownell I: The abscopal effect associated with a systemic anti-melanoma immune response. Int J Radiat Oncol Biol Phys. 2013, 85:293-95. 10.1016/j.ijrobp.2012.03.017

63. Postow MA, Callahan MK, Barker CA, Yamada Y, Yuan J, Kitano S, Mu Z, Rasalan T, Adamow M, Ritter E, Sedrak C, Jungbluth AA, Chua R, Yang AS, Roman RA, Rosner S, Benson B, Allison JP, Lesokhin AM, Gnjatic S, Wolchok JD: Immunologic correlates of the abscopal effect in a patient with melanoma. N Engl J Med. 2012, 366:925-31. 10.1056/NEJMoa1112824 